\title{
A TRAVESSIA DA MARGEM: \\ NOTAS ETNOGRÁFICAS SOBRE A MEMÓRIA COLETIVA NA TRAVESSA VENEZIANOS
}

\author{
Estevan de Negreiros Ketzer ${ }^{1}$
}

Naturalmente, tais resistências nada puderam, por muito tempo, contra o empenho de compensar, através de uma múltipla estrutura de registros, a perda de vestígios que acompanha o desaparecimento do ser humano nas massas das cidades grandes.

Walter Benjamin

Minha ambição terá sido, dia após dia, descrever essa viagem tal como a vi, eu mesmo tal como sou...

Michel Leiris

\section{Aproximações urbanas sobre a caminhada}

Esse ambiente urbano... A nós tão familiar, para mim digo estranho. É sobre esse processo que penso o movimento da cidade, quando tento significar o mundo e lhe dar um significado. É ao restituir essa condição meramente humana das classes sociais, em caminhos delirantes de conseguir coexistir e mesmo analisar um fenômeno urbano com algum tipo de rigor acerca de um saber. É nesse preciso momento que me penso como um "autor" da narrativa antropológica, história que entre muros e caminhadas parece tão viva aos que dela lêem.

A capacidade dos antropólogos de nos fazer levar a sério o que dizem tem menos a ver com uma aparência factual, ou com um ar de elegância conceitual, do

\footnotetext{
1 Discente em Psicologia pela Pontifícia Universidade Católica do Rio Grande do Sul (PUCRS) e Ciências Sociais pela Universidade Federal do Rio Grande do Sul (UFRGS).
} 
que com sua capacidade de nos convencer de que o que eles dizem resulta de haverem realmente penetrado numa outra forma de vida (ou se você realmente preferir, de terem sido penetrados por ela) - de realmente haverem, de um modo ou de outro, “estado lá”. (Geertz, 2002, p. 15)

Assim, é diante de uma narrativa que nossa expressão da realidade tenta dar luz a um sentido experimentado nesse jogo de relações sociais. Começar a caminhar pela cidade pode ser um modo de conhecer. Pode ser uma apropriação dos elementos da realidade ou uma mera forma de ficção que a imaginação toma conta? Talvez seja parte do jogo das ciências sociais, dar atenção a um momento tão efêmero e a outro uma estranha atração que nos faz traçar hipóteses. Para captar essa experiência que exige da ação cuidadosa de cada segundo misturado ao ar poluído, o temor do assalto à qualquer esquina - é necessário que a sensibilidade não se imiscua tranqüila. Não sou capaz de dar vida à dureza do concreto urbano, mas posso pensar esse fator tão elucubrado que faz das pessoas cada vez mais seres distantes do interior, fazendo das ruas novos espaços de sociabilidade. Em parte é o que parece ser a realização do dito flâneur, fazendo de si a metáfora para sua existência imiscuído na multidão.

A rua se torna moradia para o flâneur ${ }^{2}$ que, entre as fachadas dos prédios, sente-se em casa tanto quanto o burguês entre suas quatro paredes. Para ele, os letreiros esmaltados e brilhantes das firmas são um adorno de parede tão bom ou melhor que a pintura a óleo do salão burguês (...) que a vida em toda a sua diversidade, em toda a sua inesgotável riqueza de variações, só se desenvolva entre os paralelepípedos cinzentos e ante o cinzento pano de fundo do despotismo: eis o pensamento político secreto da escritura de que faziam parte as fisiologias. (Benjamin, 1995, p. 35)

É uma estranha arte de se acomodar diante das multidões e não me é possível pensar em algo mágico ou alegre, pois sinto cada vez mais que Benjamin não está no meu contexto. Vous avez fait une belle promenade ${ }^{3}$ É a modernidade que vem aos poucos caminhando nessa desagregação imagética da qual todos fazemos parte. Estaremos, como Benjamin (1995) coloca, mais próximos de flâneurs ou de peripatéticos que se botam a pensar sobre as condições existenciais? Logo, esse feitiço de fazer da cidade um lugar mais humano contrasta muito bem com as condições impostas ao trabalho no início do século XX. Talvez comece daí, das condições de vida das pessoas, a investigação que fomentou os estudos dos modos de

\footnotetext{
${ }^{2} \mathrm{O}$ significado do termo flâneur está associado àquele que caminha pela cidade, instigado principalmente pelos movimentos de pessoas. A origem do conceito é encontrada pela primeira vez em Edgar Allan Poe (2008), em seu conto $O$ homem da multidão, cujo narrador se propõe a observar pela janela de um Café as pessoas que pela rua passavam. Charles Baudelaire (1944) traduz o conto de Poe e cria o poema A uma passante, na qual a rua é a protagonista de seu lirismo. Benjamin (1995) trabalha o conceito prestando referência a uma dimensão própria da modernização da cidade e dos seus efeitos no homem.

${ }^{3}$ Você fez uma bela caminhada?
} 
viver diante do urbano, como Eunice Durham (1986) nos lembra. Onde está esse humano? Em que medida pode alguém sentir-se seguro em meio a uma multidão? "Muitas vezes, essas aglomerações possuem apenas existência estatística. Ocultam aquilo que perfaz sua real monstruosidade, ou seja, a massificação dos indivíduos por meio do acaso de seus interesses privados” (Benjamin, 1995, p. 58). Um monstro sem face me surge, tal como se eu pudesse realmente descrever meu encontro com o urbano.

Mas afinal o que é esse urbano? Talvez seja com Robert Ezra Park (1976) que nas primeiras décadas do século XX haja essa perplexidade do homem diante de um espaço em constante movimento e no qual atuam forças sociais tão distintas, não apenas pela questão de sua disposição ecológica, ma também pelo problema da organização econômica. É ele também que coloca a linguagem da Antropologia sobre o espaço urbano, buscando essa interface com os costumes e crenças. O estudo do mapeamento da cidade passa a ser também focado na interação dos habitantes e na formação de uma vizinhança, ou seja, o espaço de proximidade entre as pessoas e o seu sentimento de pertencimento à cidade, atuando junto à administração política e social. Os estudos de Wirth (1976) também se aproximam da cidade, mas pela tentativa de formar uma teoria sobre esta, inicialmente definindo a cidade como um conglomerado urbano em que múltiplas influências estão em interação.

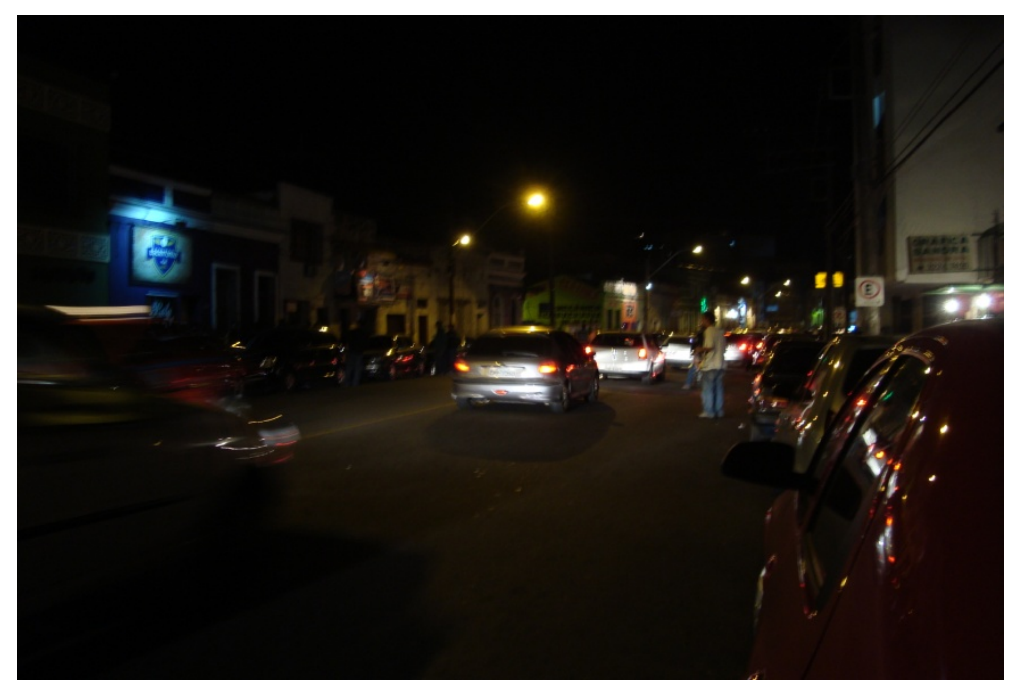

Meu olhar inicial se dirige ao entretenimento na Cidade Baixa. Houve uma noite repleta de luzes e muitos rostos conhecidos, e nela o humano pareceu sondar o concreto, mais do que na fusão de cimento, areia, pedra, cal e água, era o meu estranhamento daquilo tudo. O que afinal eu queria ver na Cidade Baixa? A resposta não era clara: não sabia nem ao certo se 
seria possível ver esse urbano como um objeto de pesquisa. Foi então que me disparou a vista de etnografar um poste de luz na antiga Travessa dos Venezianos.

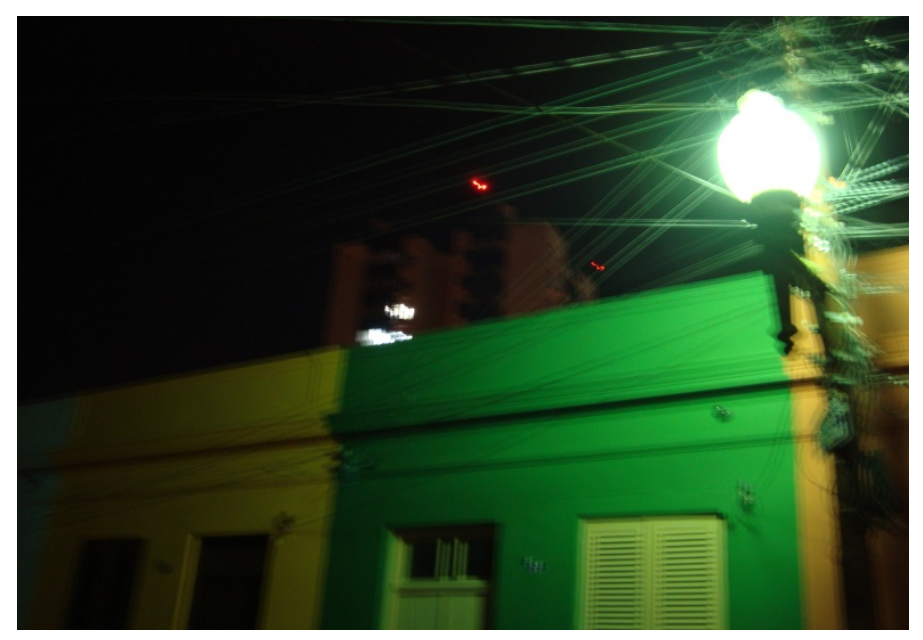

A compoteira era realmente antiga, estava tomada de fios de luz e telefone. Luz esta que provinha fraca de forma a não machucar os olhos. Havia uma placa logo abaixo escrito Travessa dos Venezianos. Por cima dela quem ali olhasse encontraria ao longe um grande prédio que fica na esquina com a José do Patrocínio. Fantástico! Estava absolutamente silencioso ali e um tanto escuro, já fora do alcance da luminosidade dos dois postes preservados no estilo epocal.

Era uma tentativa afinal de contas de que esse contato se tornasse mais estreito. Foi então nesse momento da observação tão fragmentária que fiquei sem acompanhar a velocidade do urbano na Cidade Baixa, mais propriamente, por um momento blasé na concepção de Simmel (1976). Quando voltei, indaguei: como as pessoas que dormem por ali devem se sentir com aquele barulho? Essa pergunta esteve latente no silêncio que a Travessa transmitia a quem por ali passasse.

\section{Marcas urbanas e encontro de alteridades}

A Travessa é na verdade única em toda a cidade. Foi tombada pelo Patrimônio Histórico em 1982. “O termo patrimônio, em inglês heritage, em espanhol herencia, traz no conjunto de seu significado uma relação estreita com a idéia de herança: algo a ser deixado ou transmitido para as futuras gerações.” (Sapiezinskas, 2005, s/p). O que encontramos na Travessa é uma 
situação de transferência de posse que aliada às relações de pertencimento social nos dá uma idéia de pertencimento. Os moradores que lá continuam tem a consciência de que aquele é um local tombado e que não pode ser modificado.

Após o tombamento das casas, observa-se um fluxo de incorporação do moderno e do tradicional nesse local, que se expressa no significado da rua, das casas, das coleções individuais de móveis e objetos, em ofícios herdados na infância ou juventude e em modos de fazer que combinam de diferentes maneiras essas duas características. (Sapiezinskas, 2005, s/p).

Esse modo no qual as pessoas encaram suas residências está diante de uma narrativa que elas próprias se inspiram para nos falar de seu mundo interno unido às condições de vivenciar a Travessa. Schutz (1979) recorre ao estoque de experiências acumuladas como modo de auto-interpretação que o ator pesquisado faz sobre si mesmo na relação com o mundo. “(...) o dado imediato em Psicologia é o eu”, diz Schutz (1979, p. 57) ao desenvolver sua fenomenologia dos fluxos de pensamento unida por anéis de interesses pessoais. Dessa forma, a fenomenologia nos propõe um método de investigação das atitudes humanas frente ao mundo vivido. “O método da redução fenomenológica, portanto, dá acesso à corrente de consciência em si, como um reino próprio, de natureza absolutamente única. Podemos vivenciá-la e descrever sua estrutura interna. É essa a tarefa da Psicologia Fenomenológica...” (Schutz, 1979, p. 59) É na relação entre noema (o vivenciado) e noese (o que vivencia) que se dá a fenomenologia. Busca de sentido, ela é constituída no tempo interno dos atores sociais, mas é concomitante, uma construção histórica. Será na via de um projeto que as condições do sentido subjetivo sedimentam a biografia pessoal e antecipam planos. "O projeto e a memória associam-se e articulam-se ao dar significado à vida e às ações dos indivíduos, em outros termos, à própria identidade.” (Velho, 1994, p. 101)

Sendo o campo etnográfico o espaço de construção de interpretações sobre os fenômenos humanos mais específicos e abrangentes de uma população, conforme Eunice Durham (1986, p.21): “Os estudos de comunidades permitiram um desenvolvimento particularmente fértil da antropologia, que encontrava correspondência muito próxima com a investigação de sociedades primitivas.” Assim, daquilo que se tentou empreender em comunidades indígenas as investigações urbanas buscam uma integração com através da etnometodologia ${ }^{4}$. Quando chego para iniciar, pela tarde, alguma conversa com moradores

\footnotetext{
4 A etnometodologia foi empreendida nos EUA através da Escola de Chicago, principalmente pelo desenvolvimento do Interacionismo Simbólico de Herbert Blumer (1980) que propunha três premissas: 1 - Os seres humanos agem em relação ao mundo, fundamentando-se nos significados que este lhes oferece; 2 - os significados são provenientes da relação com o mundo; 3 - os significados são interpretados pela pessoa junto
} 
do espaço, vejo o quanto o campo possui diversidades, conforme faço no meu diário de campo:

Está escrito em letras garrafais com a figura caricata de um português: "Boteco do Joaquim”. Muitos bares, todos fechados nesse horário das catorze horas. Isso é a Cidade Baixa que havia recusado recentemente. Muitas casas antigas, um escritório de advocacia, um salão de beleza, um homem jovem arrumando a fechada de uma casa. Agora falta pouco, mas estou visivelmente nervoso. Eis a Travessa dos Venezianos, adiante. Assim que entro me deparo com um lugar extremamente pacato. Numa das casas vejo de modo rudimentar com rosa choque: Gabinete de Curiosidades.

É uma loja, chegando lá são as próprias moças que me recebem. São jovens e brancas, com roupas a la hippy de boutique. Indico ser esta uma pesquisa etnográfica. A jovem me fala o nome de muitos moradores: “Não, eu não moro aqui.” Ela diz. "A maioria das casas são ateliers”. Entretanto há uma em especial. "Vai falar com a Vera, essa aí da casa à frente, verde, ela gosta muito de dar entrevistas, recebe muito bem.” Vera não estava ali, mas do outro lado da rua, voltando da vendinha. Ela se mostra muito solícita.

- Estou pesquisando como se constitui a Travessa, como foram as transformações dela... Meu pai me trouxe aqui uma vez quando eu era criança.

- Eu não sou a moradora mais antiga. A mais antiga nasceu aqui, tem livros. Posso te apresentar ela, é a Zélia.

Ela atravessa a rua e aponta com a mão na direção de um prédio de dois andares ao lado da travessa:

- Olha, ali morou um príncipe! Antigamente esse prédio era uma casa que ia até o fim da rua.

- Que príncipe era?

Ela não me responde. Vai mostrando as coisas.

- Esses prédios todos foram tombados. O arquiteto da rua está querendo fazer uma obra para tirar esses fios daqui. - Ela aponta os fios que cortam a rua. Eles estão unidos por um poste que é uma antiguidade viva! - Esse poste ficou - ela aponta para ele. - Olhe a data dessa casa - Vera diz, olhando por cima de nossas cabeças. Acompanho o movimento e ali vemos estampado o ano de 1919. Impressionante! Dona Vera fala que muita coisa tem sido preservada, mas que atualmente tem sido difícil com os bares da região.

- Tem barulho demais aqui de noite! Nós queremos que pelo menos não tenha prostituição.

Ela indica a Zélia, mais uma vez, diz que ela mesma fará o contato e marcamos para a próxima semana o encontro que infelizmente não acorreu. Inicialmente penso: "atrasos demais...” Mas pensando bem já havia atrasos em muitas outras atividades do meu cotidiano: outras cadeiras, estágio não remunerado, reunião do grupo de pesquisa, minhas aulas de francês... Essa pressa é bem de alguém altamente urbanizado, estressado com muitas coisas a

aos elementos que ela toma contato. Tal contribuição à pesquisa urbana nos possibilita pensar nossa inserção dentro do campo e aprofundar nossas dúvidas junto aos moradores. 
fazer e pouco tempo para pensar. Afinal, tenho de trabalhar, pois desejo ter uma vida com conforto! Será uma típica conclusão de pequeno burguês?

Na semana seguinte converso com Fróes, marido de Vera. Pergunto a ele como é o bairro.

- Aqui é um bairro bom. Está perto de tudo. É próximo da administração estadual, municipal, perto do parque da Redenção, do Marinha, perto dos estádios. Dá para ir para qualquer bairro da cidade com um ônibus só. É um bairro muito bom de morar.

- Ele é familiar não é?

- Mas de noite se transforma. Esse bar aí é uma barulheira de noite. A polícia já veio mais de 10 vezes ali, - Fróes me aponta uma das casas da Travessa que está com o teto quebrado - é uma barulheira, não conseguimos nem conversar a noite de tão alto.

Ele começa a me narrar muitas histórias, das mais diversas que ocorrem por ali. No intervalo seguinte a esse assunto recordo que Vera havia falado de um príncipe que por lá habitou. Fróes conhece algo acerca da história:

- Daí então a Inglaterra mantinha ele. Disseram que tomaram conta de região dele lá, a colonização. Era muito famoso. Tinha mais de 60 pessoas morando com ele lá. Dizem que até o Borges de Medeiros visitou a casa dele. Já ouviu falar?

- Não.

- Tem coisas famosas. Se tu pesquisar tem na história de Porto Alegre. Ali, naquele portão de ferro, - ele aponta para o outro lado da rua, na Joaquim Nabuco nasceu a Imperador.

- Imperador?

- A Imperador da Escola de Samba. Tem muita história. O próprio nome da Travessa vem de um bloco chamado Venezianos. As coisas estão bem preservadas. As fachadas estão bem conservadas. Ali - ele aponta novamente para a casa da frente - eles quebraram toda a cozinha original. Tem mais de 12 mil de multa. Ali apontando para um dos postes antigos - aquela placa, foi mudada. A Zero Hora trocou a placa de lugar, colocaram Travessa dos Venezianos, mas é Travessa Venezianos. Aquela outra está com o nome antigo, está só Venezianos.

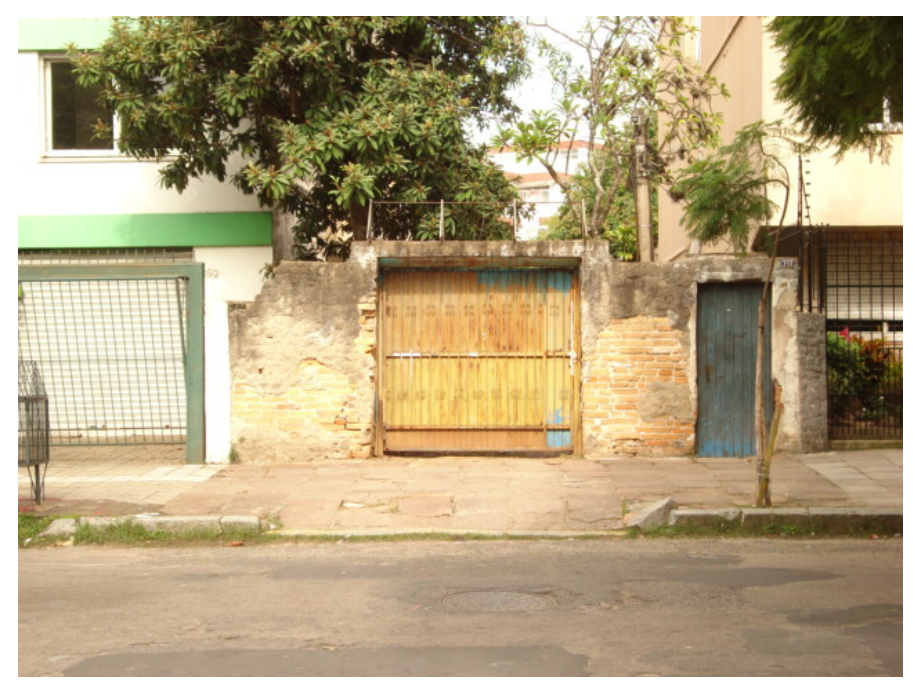


Fróes fala com vivacidade na voz sobre os feitos da Travessa. Sua fala conduz a pensar no movimento que por ali foi passando. Na semana passada tentei falar com Zélia por intermédio de Vera. Era um dia chuvoso e ao chão havia uma presilha em forma de anel. A imaginação foi até os mais altos pedestais! Uau! Será que foi do tempo da escravidão?

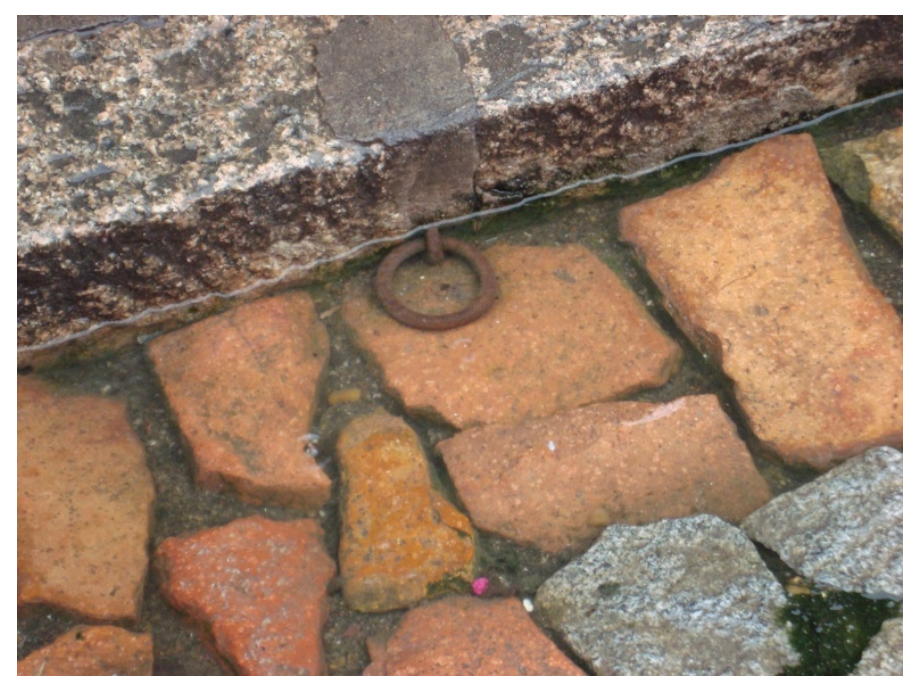

- Segunda estava bem alagado. Inclusive vi essa presilha aqui. O que é isso?

- É para prender a moto. Vinham umas escolinhas aqui, as crianças diziam “isso é do tempo dos escravos”. Mas eu é que botei!

Rimos um pouco com a situação. Eu também aproveite para rir de mim mesmo.

- Deixa eu te contar uma história então! Se você olhar aquelas duas luminárias, é diferente uma da outra, mas as duas eram igual aquela lá, bonita oh. E quando o carnaval era por aqui perto passou um grupo, dez pessoas, meio tijolo, estourou. Eu assisti eles quebrarem, mas a gente não pode nem se meter. Quebraram só por vandalismo. A prefeitura não conseguiu mais um igual e colocou um diferente.

Fróes está muito contente com a situação de entrevista, está relaxado, fumando seu cigarro. Sua esposa deixa bem claro que não quer ver ele fumando, mas ele faz que não ouve. A conversa parece findar em um momento, então ele chama sua esposa para falar, mas ela diz “não” de um dos quartos da casa, com determinação, sem demonstrar antipatia. Mostro que esse trabalho era voltado para conhecer um pouco a Travessa...

- Mas aqui é um bairro em que os moradores são muito antigos, - diz Fróes tudo tem mais de 30 anos. Mas muitos querem vender os imóveis por causa da noite. Fica muito feio. Aquilo ali, - e aponta para um casal que está fumando maconha - se drogando e urinando, ninguém, consegue dormir. Cada um que se muda é um outro bar. Vai aumentando cada vez mais.

- Foram muitos que se mudaram? 
- Já, já, foram muitos. Eu nasci em Porto Alegre e me criei em Porto Alegre. Quando eu peguei a Voluntários hoje, só casarão, mas a Voluntários já foi casa de residência. Depois se transformou só em boate. Só uma rua de vida noturna. E se deixar... E depois ficou abandonada, depois virou ruínas pra depois da rodoviária. E o bairro, Cidade Baixa, se deixar vai se transformar nisso. Esses caras de bar vêm e botam boate enquanto ta dando dinheiro. Daqui a pouco se torna uma zona perigosa, não vem mais ninguém, não dá movimento, eles terminam fechando, e ficam aí... tudo abandonado que nem na Voluntários. Por isso tem muita casa aí abandonada.

Fróes não fala explicitamente, mas ele nos convida a pensar no conceito de subúrbio, tal como Tuan (1980) problematiza em sua construção social durante o século XVIII. Estar na cidade, nessa perspectiva, é ser civilizado. É esperado ao cidadão que ele possa encontrar companhia com seus pares. "Ser sub-urbano não era exatamente ser o camponês inculto mas significava, literalmente, não ser tão urbano, ser menos urbano, não tão civil, não plenamente civilizado.” (Tuan, 1980, p. 262) Ele nos explica que tal ponto de vista está relacionado a profissões que tinham menos prestígio na sociedade e tinham de estabelecer seus espaços fora dos limites do núcleo de riquezas da cidade. Os subúrbios permanecem afastados da vida cultural do restante da cidade, pois as populações ricas não querem deixar de viver próximas ao centro, fato esse que hoje aumenta a especulação imobiliária, encarecendo o preço da moradia nesses bairros. Tuan (1980) também reforça que é aí que está a origem do movimento pendular urbano, pois o pobre vai aos poucos se afastando dos centros urbanos e com isso trabalha perto de onde mora, nas fábricas, florescendo por vezes com o surgimento de grandes avenidas, como Fróes nos indica em sua fala no caso da Avenida Voluntários da Pátria.

A fala de Fróes também conduz a uma certa aproximação da saudade de um tempo antigo. Pensar esta fala pode nos levar a uma naturalização e introjeção do fenômeno urbano, até os estatutos econômicos. Todavia, essa é também uma construção pessoal dele. Maurice Halbwachs (2009) reconhece como sendo a memória coletiva dentro do espaço social. "Cada aspecto, cada detalhe desse lugar tem um sentido que as partes do espaço para os membros do grupo, porque todas as partes do espaço que ele ocupou correspondem a outros tantos aspectos diferentes da estrutura e da vida de sua sociedade, pelo menos o que nela havia de mais estável.” (Halbwachs, 2009, p. 160) Essa estabilidade é representada nas relações sociais, pois uma vez firmada a memória na comunidade é ela que passa a estar de todo dentro da vida das pessoas e estas passam a reconhecê-la como algo representativo. Fróes fala de uma realidade em que os costumes sociais estão imbricados em um modo de fazer as transformações ocorrerem, mesmo que na forma de degradação. Nesse sentido, a transformação da Travessa em patrimônio histórico não é simplesmente a solidificação da 
memória coletiva, mas é no anteparo com a nova cidade que nasce uma forma de reconhecimento da passagem do tempo. Tempo que passa nos indica as grandes transformações urbanas.

- Aqui também era a Ilhota? - Pergunto na curiosidade.

- Aqui não - Diz ele. - Dizem que era Ilhota porque era cheio de canaizinhos.

Ficamos em silêncio. Ele explica como era o canal que passava o Dilúvio. A João Alfredo era a rua da Margem. Era por onde passava o Dilúvio. A José do Patrocínio era a Rua da Concórdia. Eu não morava nessa zona. Peguei o tempo que só era possível passar ali pelo Parobé, passando pela ponte de pedra. Era quase uma coisa separada, uma ilha. Ali mais em cima era a rua da Olaria, porque aplicavam os tijolos, telhas. Se você olhar com cuidado vai ver que a arquitetura do shopping é uma homenagem à Travessa dos Venezianos!

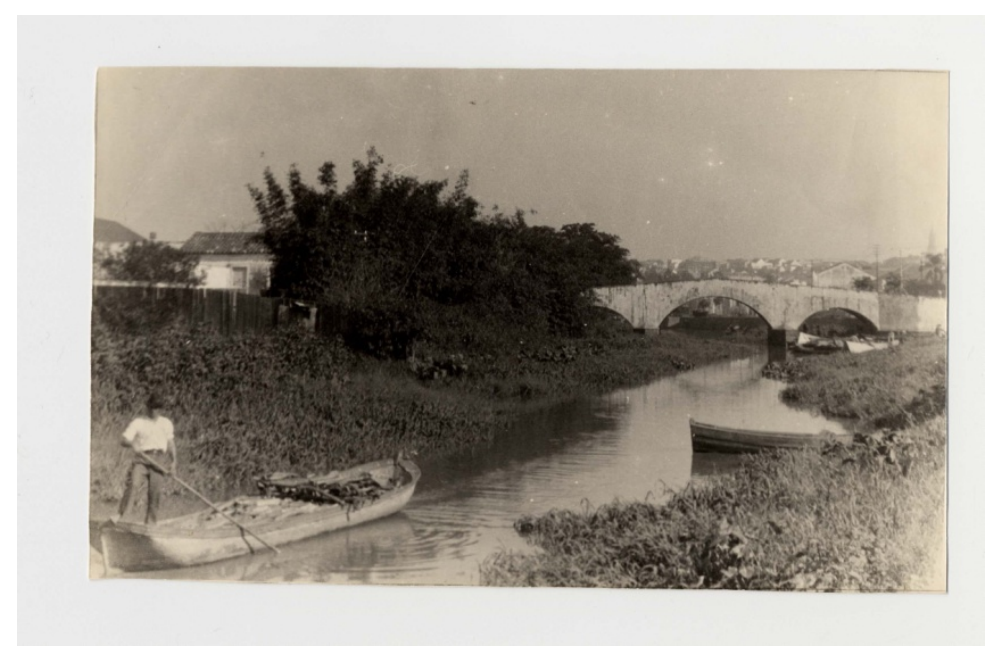

ACERVO DO MUSEU JOAQUIM JOSÉ FELIZARDO / FOTOTECA SIOMA BREITMAN

A Travessa parece tanto um ponto no passado a ser lembrado no presente, mas não me dava conta do quanto essa interface refletia o modo pelo qual a vida dessas pessoas adquire uma história tão verdadeira. Buscando no passado essas pessoas me falavam da vida que levavam hoje, dali retiravam algo que as caracterizavam como moradores da Travessa. Esse tempo de outrora se chamava Rua da Margem, a origem simbólica de um passado anterior a todos que quiseram conversar sobre a Travessa, mas que sempre fazia menção a esse tempo desconhecido. Foi muito difícil visualizar esse tempo, era preciso algo mais consistente. Ao vislumbrar as fotos antigas do Museu Joaquim José Felizardo, podemos constatar grandes mudanças urbanísticas nessa região. 


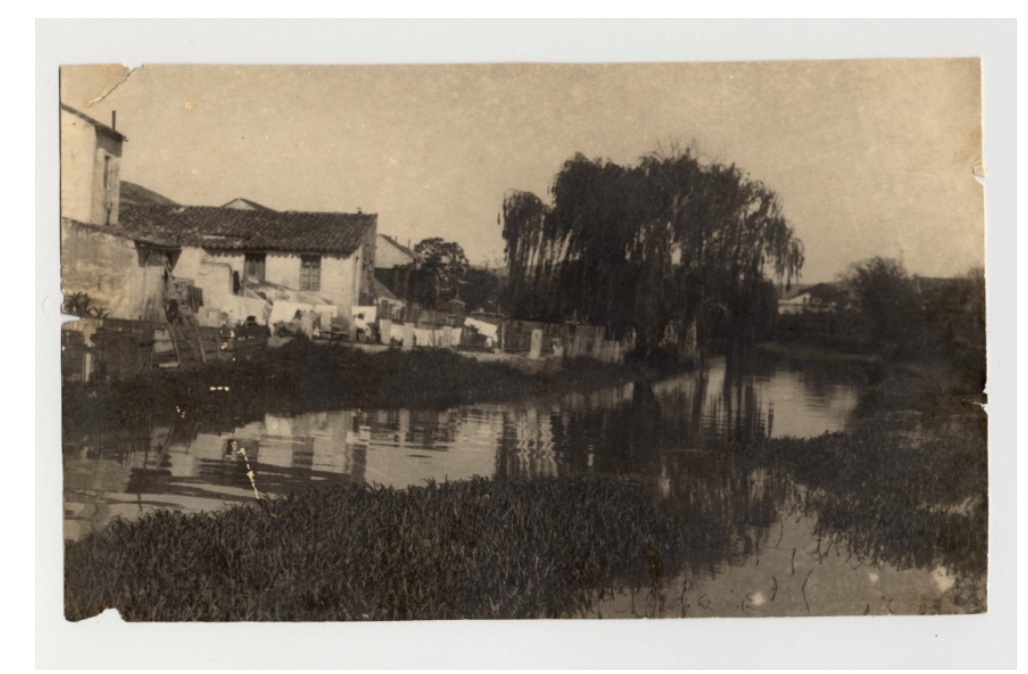

ACERVO DO MUSEU JOAQUIM JOSÉ FELIZARDO / FOTOTECA SIOMA BREITMAN

A Rua da Margem se localizava de frente ao Arroio Dilúvio. Até 1959 não sofrera transformações. A partir desse ano o Arroio tem seu fluxo mudado, passando então por uma das mais importantes transformações urbanísticas de Porto Alegre em toda a sua história, cujo fator principal era justamente a expansão da cidade. O arroio que outrora era limpo e possibilitava subsistência a famílias de pescadores, hoje faz parte do sistema de esgotos da cidade.

Nos anos de 1960 observamos a grande mudança de nome da Rua da Margem para Rua João Alfredo, tornando-se esta uma rua asfaltada. Esta característica é antes de tudo um modo de integralização da cidade em um ambiente que, como vimos, desperta curiosidade. Para quem vive lá tal ambiente surge como apropriação de um espaço protetor. Os perigos se comunicam contra aquilo que pela diferença pode ameaçar a continuidade de um legado, aquilo que a tradição luta para preservar (Halbwachs, 2009).

O horizonte da tradição não está perdido, mas se adapta ao tempo como Halbwachs (2009, p. 164) parece nos mostrar: “(...) um grupo não se contenta em manifestar o que sofre, em se indignar e protestar na hora. Ele resiste com toda a força de suas tradições e essa resistência tem suas conseqüências. Ele procura e em parte consegue reencontrar seu antigo equilíbrio nas novas condições.”

Fróes disse rindo que não saberia o que mais poderia me dizer. Desligo o gravador nesse momento e... 


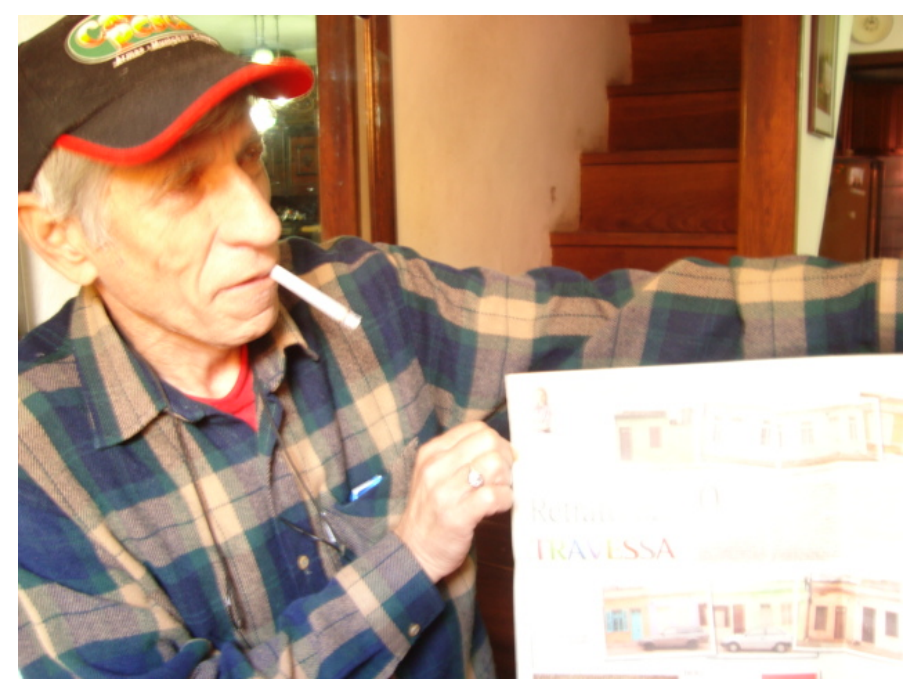

ele me convida a entrar em sua casa. Mostra-me matérias feitas sobre a Travessa e uma foto que foi premiada com sua casa toda decorada. Diz que essa foto ganhou um prêmio no exterior. Ele também aproveita para me mostrar sua coleção de vídeos e CD’s dos Beatles. Mostra um documentário que fizeram sobre ele em que é um especialista nos Beatles. de 1996.

- Olha como a Travessa estava feia nessa época! - Enquanto mostra um vídeo

- Ah Fróes - diz sua esposa pesarosa - não foi para isso que ele veio aqui...

- Calma mulher! - Calmamente ele acende um novo cigarro enquanto me mostra seus vídeos.

Na semana seguinte, foi marcada uma entrevista com o Pai Alfredo, dono de um Centro Africano que se localiza dentro da Travessa, ele me fala poucas coisas sobre a Travessa, mas muitas acerca de sua família. Ao repensar os pontos de referência da Travessa, habitam muitos elementos que unem as pessoas dali.

- Agora tem poucos moradores antigos, eu aqui, a vizinha ali... Os outros são novos, praticamente virou esses ateliers. Agora praticamente virou comercial. Foi mudando muita coisa. Na época que o pessoal morava aqui todo mundo se reunia... era São João, tinha o casamento da roça... Uns foram morrendo. No caso, meu pai morou aqui e ele pegou a enchente de 1940. Tem irmão meu que nasceu aqui e que se fosse vivo teria 50 anos. Não vou te dizer que não continue bom, até continua bom, mas na época da minha mãe e do meu pai eles dormiam de porta aberta. Era tranqüilo. (...) Sem contar esses bares, é uma esculhambação danada. A gente chega de madrugada e não tem como estacionar o carro na frente de casa. Ta tudo lotado e ainda ficam bravos com a gente. Eu faço bagunça de madrugada. Não quero nem saber, mando chamar, tirar, não vou botar o carro lá na esquina!

O Príncipe Custódio sempre entra nas conversas, os moradores lembram desse episódio com louvor. "Eu não conheci, só ouvi falar. Conheço a neta dele que de vez em quando vem na minha casa”, fala Pai Alfredo. E claro também é feita a relação com o tipo de trabalho de Pai Alfredo com o que pudesse ter parentesco com a África: “O centro dele é outra bacia, não 
tem relação com o meu centro.” Fico ouvindo o que ele pode me contar. Pai Alfredo tem em torno de 40 anos, negro e corpulento, sua voz grave dá uma sensação de tranqüilidade. “A casa foi comprada com o primeiro salário do meu pai, não sei te dizer como, mas comprou. A minha família foi fundadora do clube Floresta Aurora, Sociedade Floresta Aurora. Teve uma época que tinha bloco. Já nem tem mais ninguém, passaram a diretoria. Dos antigos não tem ninguém. Foi fundado na Lima e Silva, onde é o Zaffari hoje.” A esposa de Pai Alfredo está limpando a sala. Incomoda competir com o aspirador de pó e a televisão. No início chega uma mulher que senta, ficando na minha frente. Ela marcou hora com Pai Alfredo também. "Esse aqui era o pátio da casa do Príncipe Custódio. A casa dele era toda a esquina até o fim da rua. Só ficou a fachada. Aqui não mudou muito.”

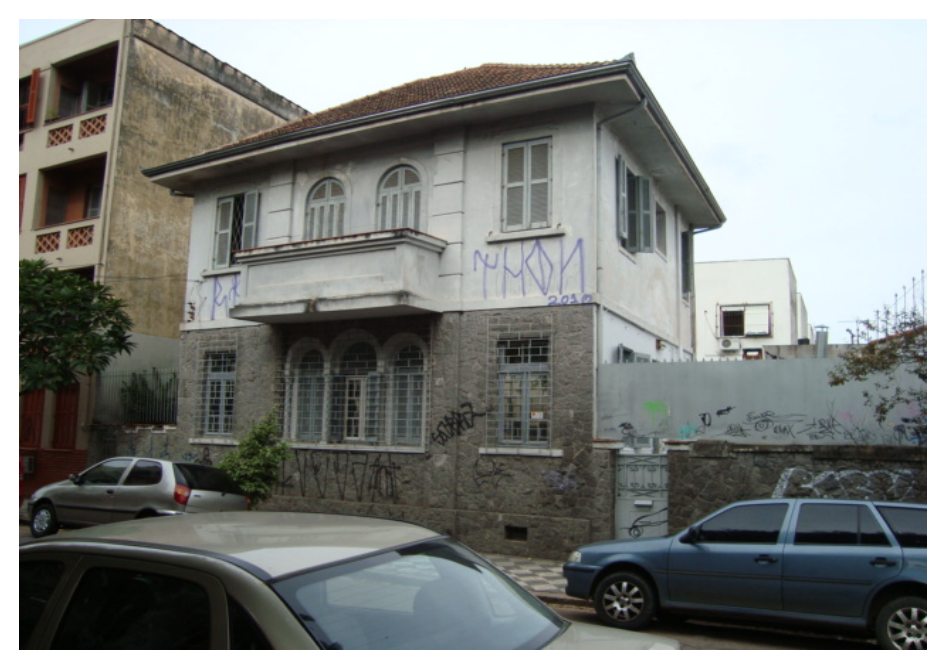

Pai Alfredo tinha mais compromissos naquele momento. Os planos eram, inicialmente, buscar os moradores mais antigos para conversar. Vera me indicou Zélia desde o início, por ser a moradora mais antiga, e ela finalmente "aconteceria” na semana vindoura.

\section{Reconstrução da memória coletiva}

Era fim de tarde, véspera do feriado de Corpus Christi, dia 2 de junho, às 17h30min. A Travessa estava com uma grande quantidade de carros estacionados, algo que não fora visto até aquele momento. Vera informou que não teve tempo para falar com Zélia, mas ela estava em casa e, portanto, lá eu poderia encontrá-la. Ao bater em sua porta, mesmo explicando os objetivos da pesquisa ela se mostra indisponível. 
Não adiantou dessa vez. Pelo menos ela não foi grosseira. Melhor voltar à casa de Vera e ver o que fazer.

- Fala lá com o Rodrigo, ele vai te ajudar. - Vera responde com pressa, mas disposta em ajudar.

Rodrigo convida a entrar em sua residência após minha sucinta apresentação. Corrijo: ali não era uma residência. Aquilo era certamente um atelier e ele devia ser um artista pelas paredes mal rebocadas, as mesas de desenho atrolhadas de pepéis sobre a superfície. Há um quadro feito a partir de quatro divisões na tela e letras garrafais desenhadas. É assinado por uma tal de Carol S.A.

Aí começa a despertar a agudeza da situação: havia elementos demais, eu estava perplexo com a situação de Zélia, mas o foco de atenção mudou subitamente. "Com a expansão da comunicação e da influência intercultural, as pessoas interpretam os outros, e a si mesmas, numa desnorteante diversidade de idiomas.” (Clifford, 1998, p. 19) As preocupações com aquele espaço em constante movimento e a decepção de não falar com a moradora mais antiga da Travessa, a fim de tentar reconstituir a experiência humana dessa comunidade, apareciam como cenas de um aparente fracasso. Havia agora esse momento meio incerto de contato com um morador novo da Travessa. O trabalho parecia meio disperso... Paul Ricoeur (1997, p. 192) compreende esse momento como uma relação de transição mediada por um nível de representação simbólica muito próxima. “Sobre essa simultaneidade de dois distintos fluxos de consciência é que se edifica a contemporaneidade, que se estende muito além do campo das relações interpessoais, garantidas no contato pessoal.” O autor tem em mira as relações que são distintas, aquelas em que a ruptura no modo de experenciar é propriamente no aqui e agora e não pela via imaginativa. Nesse sentido, a memória do passado está em interseção com a memória do presente, daqueles que ficam aqui, quebrando o anonimato dos que já estiveram. Dessa forma a compreensão da natureza simbólica não é garantida pela condição inicial de um objetivo etnográfico ileso ou específico. É aí que duvidamos do aparente “dado” de pesquisa.

(...) o ato de compreender os outros inicialmente deriva do simples fato da coexistência num mundo que é partilhado; mas esse mundo experiencial, um terreno intersubjetivo para formas objetivas de conhecimento, é precisamente o que falta, ou é problemático, para um etnógrafo ao penetrar uma cultura estrangeira. (Clifford, 1998, p. 35)

Enquanto sentados no sofá daquela casa de paredes brancas recém pintadas em seu interior e sem intenção de disfarçar o reboco caído. Do outro lado da rua, a música de Cazuza, bem alta, e uma tropa de carros que estacionam paulatinamente em toda a Travessa. As luzes do bar que vislumbrava de dentro da casa de Rodrigo são de um amarelo queimado muito antigo, a decoração das paredes era tomada de livros velhos e ainda não havia clientes nas 
imediações. "Você tem de ver o tamanho do pátio deles! Toma um chope lá e pede para eles te mostrarem!”

Rodrigo me aponta uma escada enferrujada em que a única passagem para ela se dá por via de uma janela.

- Se tu quiser dá uma subida lá em cima para ver os fundos da Travessa. materiais

Eu me atrevo a subir. Era possível ver a cozinha repleta de caixas cheias de

- Vem aqui e leva esse troço embora! - É Rodrigo que fala com um rapaz, que chega pouco depois de minha entrada. Eles falam sobre outras pessoas e da inutilidade que os papéis estavam fazendo dentro de uma caixa.

Enquanto isso a subida...

- Só não vai se matar aí, meu!

- Tudo bem! Eu acho que consigo... - A escada era de metal, altamente enferrujada. Seu único acesso era por uma janela.

- A dona não devia entrar por aí. - me alertou Rodrigo. A porta que dava acesso estava solidamente trancada. Bom, então eu tentarei ser um etnógrafo! Dei com a canela no marco da janela. Excelente! Mas era de se prever isso, afinal por algum motivo não fui fazer etnografia na Amazônia. Ao chegar ao final da escada encontro várias telhas enfileiradas, pensei "se um desavisado não se dá conta, escorrega e cai de cara no chão!” De frente uma cerca elétrica com o lembrete de alta voltagem. Do lado esquerdo, está a casa da Zélia e havia duas luzes acesas. Não enxerguei muita coisa, era só um grande varal, separados por grades de ferro. À direita, duas janelas de uma casa de moradores. E, finalmente, às minhas costas, as telhas da casa de Rodrigo. Tento tirar fotos, mas a máquina não tira com flash, estranhamente. Quando Rodrigo sobe diz que tem uma igual, mas que não sabe porque a máquina não tira flash. Ele ajusta a definição da câmera para uma resolução melhor.

Resolvemos descer.

- Não sei como é que a moradora antiga conseguia subir e descer daqui. Outro comentário dele. - Só tinha um varal aqui antes dela morrer. Era uma velhinha quando morreu.

- Essa casa é sua?

- Eu alugo ela. É de um amigo meu. Estamos nesse domingo promovendo a Desvenda. É uma feira de arte contemporânea. Sobre o que é a tua pesquisa? - Ele fez essa pergunta muito rapidamente.

Sentados no sofá começamos a conversar, agora de frente ao bar e à música de Cazuza. Rodrigo era jovem, deve ter uns trinta anos, talvez menos. Usa óculos em forma de Ray-Ban antigo, mas de grau, barba fina, moletom de lã e sua cor de pele é branca.

É então que Rodrigo explica sobre a Travessa, sua visão de lá.

- Aqui é diferente. As pessoas estão como se fosse no interior. Parou no tempo. Muitos não gostam de nada novo, os mais velhos principalmente. Quando eu cheguei aqui eles não gostavam de mim, mas fica um tempo assim, depois nós já conversamos. Estou aqui já faz um ano, dois anos, entrei em 2008. O pessoal daqui sempre foi pobre. Isso é como uma ilha: tem gente rica demais em volta. Nós queremos fechar a rua para os carros, não tem que ficar passando mais, tem de ser para quem mora. 
Uma população pobre enfrenta problemas ao se deslocar. Deixar o espaço é como deixar a si mesmos. "Por trás das novas fachadas, por avenidas bordadas de ricas mansões recentemente construídas, nos pátios, nas travessas, nas ruelas dos arredores, se abriga a vida popular de outrora, recuando passo a passo. É assim que nos surpreendemos ao encontrar ilhotas arcaicas em meio a bairros novos.” (Halbwachs, 2009, p. 164). A Travessa está cheia de carros nesse momento e são carros novos. Há cada vez mais deles chegando e pessoas caminhando pela Travessa. Três meninas negras brincam com seus vestidos floridos, correndo de um lado ao outro e rindo alto, provavelmente são moradoras da comunidade. A noite cai. É véspera de feriado, e surge esse insight: as pessoas geralmente saem em véspera de feriado. Ouviam-se muitos sons na rua.

- É um problema aqui - continua ele. - Está tudo tombado, mas não vem nenhum dinheiro! Para cobrar eles sempre vem e vistoriam a casa de todos... São bem rápidos! Mas para ajudar o pessoal a preservar aí não. Aqui sempre foi de gente pobre sabia? Pode ver que a população dos que permanecem é de negros. Ali do outro lado são pessoas que alugam para trabalhar com arte, tem o Chico Lisboa, mais uma oficina louca no fim. Quando vim para cá você tinha que ver! Mas depois passou. Final de semana o pessoal gosta de abrir as portas e ficar ouvindo música, é outra coisa! Por isso é que dá esses choques.

Era importante saber como os outros moradores encaravam a entrada dele na comunidade.

\footnotetext{
- Eu com o tempo fui bem aceito. A Zélia ainda torce o nariz para mim, mas a Vera sempre me dá apoio. Fazemos festa junina aqui, fazemos uma fogueira!

- Sério?

- Sim, todos participam. É um clima bem de vizinhança. Decidimos as coisas bem no meio da rua aqui. As crianças de manhã brincam juntas aqui. É incrível, bem coisa de interior.
}

Essa participação de Rodrigo dentro da Travessa dá vistas a uma forma de troca a partir de outro lugar. De fora um estrangeiro, de dentro Rodrigo também passa pela situação desconfortável da não aceitação. Seu lugar é questionado, segundo ele. Para ser considerado alguém não precisou passar por um ritual maior do que todo o fluxo da modernidade nos faz passar: Rodrigo participou aos poucos de uma experiência de “personificação” dentro da comunidade, vestindo uma máscara social. "O homem, com elas, fabrica-se uma personalidade superposta, verdadeira na situação de ritual, fingida na situação de jogo. Porém, entre uma pintura de cabeça ou de corpo, e uma roupagem e uma máscara, só há uma diferença de grau e nenhuma diferença de função.” (Mauss, 1974, p. 222). A metáfora utilizada pelo etnólogo diz respeito a um campo do "eu” que excede o mero individualismo 
das relações modernas. Nasce daí um ser social, palavras que são anotadas em um certo momento, mas não são ditas a todo o momento, modos de pensar e sentir que não possuem a mesma repercussão. A máscara tem um uso criado pelo coletivo para dar conta de uma parcela muito pessoal que carece sempre de representação. Rodrigo conquista uma posição de pessoa dentro da Travessa e isso não é privilégio dele apenas. Quando Fróes me mostra seus discos dos Beatles, ele me mostra a máscara de sua aceitação social. Pai Alfredo também me convida a entrar em sua casa, ele mesmo já consolidado em seu Centro Africano.

- Eu te aconselho a falar com os moradores jovens da Travessa. Eles estão aqui há menos tempo, se mudaram ano passado para cá. É capaz deles estarem aqui, ainda. Mas agora eu vou ter de falar com a dona da loja aqui do lado.

E nesse ponto a meio caminho do tempo presente e do tempo passado, em que a interpretação, seja lá qual for, toma um ponto de partida muito interessante: ela possui múltiplos discursos, como enuncia James Clifford (1995, p. 36) cuja “ 'experiência' etnográfica pode ser encarada como a construção de um mundo comum de significados, a partir de estilos intuitivos de sentimento, percepção e inferências. Essa atividade faz uso de pistas, traços, gestos e restos de sentido antes de desenvolver interpretações estáveis.”

O foco de trabalho inicial talvez não pudesse alcançar a complexidade que a Travessa possuía. A narrativa, nesse ponto, não se encerra às necessidades daqueles que são etnografados, mas são também, em parte, necessidades do etnógrafo diante do fenômeno urbano. São elas que invadem um espaço de interações e interesses muito dissonantes e certamente polifônicos, descentrados de um eixo horizontal de entendimento. A categoria se amplia e permite que possamos pensar sobre o que de fato é narrado unido a uma vertente da comunidade ou mesmo na conversão dos dados pela mente do etnógrafo. Heteroglossia das diversidades instáveis e certamente delimitadas, pois é sempre uma fração das experiências e do fluxo de pensamentos incluindo aí quando há dissonâncias entre eles e nós. Parece que tudo é um grande “eu” que padece de uma boa interpretação.

\section{Considerações finais}

Essa pesquisa está inconclusa. Inconclusa do ponto de vista de quem busca conhecer uma realidade, interpretar os dados e fazer deles uma representação da realidade. Não sei ao certo se encontrei a Travessa Venezianos, tal como uma memória coletiva “estável”. Através do lento (di)vagar e das considerações críveis da experiência empírica unidas às formas de 
imaginários urbanos como vi nas falas dos entrevistados. Mesmo assim há algo que nossa experiência não capta mesmo diante do outro: o fato irrepresentável de que o outro possui uma história que transcende a ele mesmo e o eleva ao patamar demiúrgico de sua existência.

A Travessa Venezianos é um lugar que impera como ruína que as pessoas ao certo já não conseguem lembrar sem antes esquecerem alguma coisa no meio do caminho. Com Rodrigo a Travessa era um Patrimônio, reconhecido como pelos seus antigos moradores. Mas como ele marca esse Patrimônio é certamente diferente do restante da Travessa. Que marca é essa que fica na sociedade mesmo? As pessoas parecem conciliar facilmente a Travessa e a diversão de final de semana na Cidade Baixa. A memória da Travessa que sobrevive a nós será tão clara assim perto dos prédios, da poluição, do vandalismo, da miséria iminente? É algo que no íntimo do "eu” possui a tradição e a renovação da categoria de análise que a linguagem dos "nativos” ostenta. Seria, então, esse olhar sobre o urbano uma utopia possível? Estranhamento tão entranhado em nós que precisamos de tempo para pensar mais um pouco?

Mais do que a categoria de análise, à parte de um grande amontoado de expressões, gestos e rastros que muitas vezes não explicam bem o que faço ali, sem qualquer estabilidade como elabora James Clifford (1998). Mesmo que muitas vezes esses rastros não sejam um sinal de verossimilhança - sem cair numa total ficcionalização da realidade - estes nos mostram um certo embaraço:

\footnotetext{
Podemos tornar a examinar os azandes, mas, se não for encontrada a complexa teoria da paixão, do conhecimento e da causalidade que Evans-Pritchard disse ter descoberto lá, é mais provável que duvidemos de nossos próprios poderes de observação do que dos dele - ou, quem sabe, que concluamos simplesmente que os azandes já não são os mesmos. (Geertz, 2002, p. 16).
}

Até que ponto é possível ser ortodoxo em uma área de conhecimento que nunca, na realidade, criou princípios realmente compartilhados por seus praticantes?

Sabemos, no entanto, que Lévi-Strauss passou semanas com os Nambiquara, Evans-Pritchard não mais de alguns meses com os Nuer e que Marcel Mauss só realizou uma rápida viagem de estudos pelo Marrocos, o que não impediu que construíssem obras ricas e definitivas. Seriam exceções, figuras ímpares, impossíveis de servirem de modelo devido a sua excepcionalidade? Ou seriam demonstração clara de que não há cânones nem regras rígidas em um trabalho que depende muito de sensibilidade e intuição? (Velho, 1980, p. 14)

As alternativas levantadas mostram a fragilidade da interpretação diante da alteridade. Essa alternativa também é uma busca pelo projeto pessoal a partir da análise cultural, este se torna o conjunto de idéias orientadas no tempo e espaço (Velho, 1981). Tal noção sempre faz 
alusão às emoções mais profundas que observamos com tanta delicadeza quando nos empenhamos ao ouvir histórias e tentar reproduzi-las na busca de uma organização narratológica coerente. Nisso não podemos deixar de lado, ao tomar nota, tirando fotos, traçando roteiros etnográficos, também realizamos um ato de esquecer, deixamos que elementos nascessem para que outros fenecessem, com a fragilidade da escrita de um mundo letrado, vestígios e rastros do que passou por nós e hoje habita a cidade. Fantasmas como Michel Leiris (2007) anuncia sem grande força de esperança uma África já enfraquecida, tentando despertar de um sono profundo. Enceta no imaginário de quem participa sem dele perceber. Torna-se fantasma dele próprio, mas tão real, pois habita a íntima possibilidade de temê-lo nessa incrível força magnética que nos liga ao mundo.

\section{Referências}

BENJAMIN, Walter. Charles Baudelaire: um lírico no auge do capitalismo. In: Obras Escolhidas III. São Paulo: Editora Brasiliense, 1995, v. 3.

BLUMER, Herbert. A natureza do interacionismo simbólico. In: MORTENSEN, C. D. (Org.). Teoria da comunicação: textos básicos. São Paulo: Mosaico, 1980.

CLIFFORD, James. A Experiência Etnográfica: antropologia e literatura no século XX. Rio de Janeiro: Editora UFRJ, 1998.

DURHAM, Eunice R. A Pesquisa Antropológica Com Populações Urbanas: problemas e perspectivas. In: CARDOSO, Ruth. A Aventura Antropológica. Teoria e Pesquisa. Rio de Janeiro: Paz e Terra, 1986.

GEERTZ, Clifford. Obras e Vidas: o antropólogo como autor. Rio de Janeiro: Editora UFRJ, 2002.

HALBWACHS, Maurice. A Memória Coletiva. São Paulo: Centauro Editora, 2009.

LEIRIS, Michel. A África Fantasma. São Paulo: Cosac Naif, 2007.

MAUSS, Marcel. Sociologia e Antropologia. São Paulo: EPU-EDUSP, 1974.

RICOEUR, Paul. Tempo e Narrativa. Campinas: Papirus, 1997.

SAPIEZINSKAS, Aline. Herança, sacralidade e poder: sobre as diferentes categorias do patrimônio histórico e cultural no Brasil. Horiz. antropol., Porto Alegre, v. 11, n. 23, June 
2005. Disponível em: <http://www.scielo.br/scielo.php?script=sci_arttext\&pid=S010471832005000100009\&lng=en\&nrm=iso>. Accesso em 05 June 2010.

SCHUTZ, Alfred. Fenomenologia e Relações Sociais. Rio de Janeiro: Zahar Editores, 1979.

SIMMEL, Georg. A Metrópole e a Vida Mental. In: VELHO, Otávio Guilherme (org.). O Fenômeno Urbano. Rio de Janeiro: Zahar Editores, 1967.

VELHO, Gilberto. O antropólogo pesquisando em sua cidade: sobre conhecimento e heresia. In: VELHO, Gilberto (coord.). O desafio da cidade. Novas perspectivas da Antropologia Brasileira. Rio de Janeiro: Compus, 1980.

VELHO, Gilberto. Individualismo e Cultura: notas para uma antropologia da sociedade contemporânea. Rio de Janeiro: Zahar Editores, 1981.

VELHO, Gilberto. Projeto e Metamorfose: antropologia das sociedades complexas. Rio de Janeiro: Zahar Editores, 1994. 